\title{
PENGARUH PENGGUNAAN MEDIA PEMBELAJARAN AUDIO VISUAL TERHADAP PEMBIASAAN BERPERILAKU BAIK PADA ANAK KELOMPOK A
}

\author{
Achmadi \\ PG - PAUD FKIP Universitas PGRI Adi Buana Surabaya \\ email: ajisyauqi04@yahoo.com
}

\begin{abstract}
Abstrak
Masih ditemui beberapa anak yang mengalami kesulitan dalam mengikuti program pembiasaan di Taman Kanak Kanak. Misalnya masih ada anak yang belum terbiasa melakukan bersalaman (berjabat tangan) pada saat bertemu dengan gurunya. Ada anak yang kurang peduli / tidak mau melakukan kegiatan di kelas sesuai dengan aturan yang ditetapkan gurunya. Ada anak yang tidak mau /tidak peduli untuk membantu teman yang sedang memerlukan bantuan, dan sebagainya. Padahal pembentukan sikap atau perilaku untuk anak usia dini melalui program pembiasaan. Program pembiasaan merupakan proses pembentukan sikap atau perilaku yang relatif menetap dan bersifat otomatis, serta melalui proses pembelajaran yang berulang ulang dilakukan setiap hari di sekolah. Bertolak dari kondisi tersebut maka kesulitan atau masalah dalam program pembiasaan perlu diteliti. Tujuan dari penelitian ini adalah untuk mengetahui pengaruh tayangan audiovisual terhadap program pembiasaan, khususnya dalam upaya peningkatan hasil program pembiasaan untuk anak usia dini. Penelitian ini menggunakan kuasi eksperimen dengan rancangan treatmen by subject untuk menganalisis perbedaan sebuah penelitian eksperimen yang terjadi dalam one group desain. Pola penelitiannya dengan pola pre tes - tindakan - pos tes, terhadap penggunaan media pembelajaran Audio Visual. Sedang pengumpulan datanya menggunakan tes perbuatan dan, observasi. Metode analisa data yang digunakan adalah analisa statistik $u j i$ - $t$. Hasil penelitian menunjukkan bahwa pembelajaran dengan tayangan audio visual yang bisa dilihat, bisa ditiru, bisa dirasa dan bisa didengar sangat efektif dalam meningkatkan program pembiasaan untuk anak usia dini.
\end{abstract}

Kata Kunci : Program Pembiasaan, Media Audio Visual

\section{A. PENDAHULUAN}

Program pembiasaan yang dilakukan di Taman Kanak Kanak diarahkan untuk mengembangkan kecakapan hidup (soft dan hard skill). Tujuannya adalah untuk mengembangkan : (1) kemampuan mencintai diri sendiri, yaitu melalui mengenal, menerima, dan mengarahkan diri (2) kemampuan mencintai orang lain melalui bekerjasama dan berkolaborasi, menolong, toleran, dan empatik

Secara ideal anak usia 5-6 tahun sudah harus memiliki kemampuan berperilaku baik dan memiliki kecakapan hidup.. Sebagai indikatornya adalah : 1). Anak mau dan dapat berjabat tangan dengan benar. 2). Anak bersedia memberi pertolongan dan mau meminta tolong dengan baik bila ada permasalahan. 3). Anak mau dan dapat melaksanakan aturan di sekolah sesuai dengan ketentuan . 4). Anak mau bergaul dan berinteraksi sosial dengan teman teman di kelasnnya. Namun fakta di lapangan ditemui bahwa anak seusia 5 6 tahun masih ada yang belum memiliki kemampuan tersebut secara optimal. Salah satu penyebabnya adalah pembentukan perilaku untuk anak usia dini itu kurang tepat. Bentuk ketidak tepatan tersebut antara lain : (1) Penggunaan media pembelajaran yang tidak / kurang bervariatip, yakni Guru hanya menggunakan media gambar sebagai contoh sikap baik dan sikap yang tidak baik (2) Guru dalam memberikan contoh berperilaku, sulit diterima oleh anak atau untuk memahaminya memerlukan waktu yang cukup lama (3) Cara menjelaskan tentang sikap / perilaku banyak menggunakan bentuk verbal, sehingga pemahaman anak sangat dangkal atau verbalisme (4) Kurangnya dukungan atau contoh-contoh riil dalam mengetrapkan suatu perilaku. Misalnya waktu anak 
di rumah atau pada saat jam luar sekolah anak tidak mendapat penguatan atau reward dari orang di sekitarnya bahwa anak telah berperilaku baik.

Bertolak dari permasalahan tersebut diatas, maka salah satu bentuk pemecahannya adalah melaksanakan program pembiasaan dengan pembelajaran menggunakan media audio visual. Sebab media ini dapat dilihat, didengar, dirasakan, dan ditirukan oleh anak. Untuk itu penulis berkeinginan untuk megkaji dan meneliti permasalahan tersebut dengan judul : "Pengaruh Penggunaan Media Pembelajaran Audio Visual terhadap Pembiasaan Berperilaku Baik pada anak kelompok A TK Dharma Wanita Ds. Wedi, Kecamatan Gedangan, Kabupaten Sidoarjo".

\section{B. METODE PNELITIAN}

Jenis Penelitian yang digunakan dalam penelitian ini adalah metode Kuasi eksperimental yaitu pre test - post test one group desaign, dengan rancangan treatment by subyek. Yaitu menganalisa perbedaan dalam satu group sampel dengan pola penelitian sebagai berikut:$$
\mathrm{O}_{1} \rightarrow \mathrm{X} \rightarrow \mathrm{O}_{2}
$$

Keterangan:

$\mathrm{O}_{1}=$ Pre test

$\mathrm{O}_{2}=$ Post test

$\mathrm{X}=$ Perlakuan (pembelajaran tentang program pembiasaan dengan menggunakan media audio visual.

Adapun yang mwnjadi subyek dalam penelitian ini adalah anak TK kelompok A yang berjumlah 34 anak terdiri dari 13 laki-laki dan 21 perempuan. Metode pengumpul data menggunakan tes perbuatan dan observasi.

Metode Test perbuatan dilakukan dengan cara meminta anak untuk menunjukkan contoh berperilaku sesuai dengan program pembiasaan. Sedang metode observasi digunakan untuk mengamati perilaku anak pada saat mengikuti kegiatan di Taman Kanak Kanak yakni tentang sikap : 1). Bila bertemu denan guru dan temannya mau berjabat tangan dan mengucapkan salam. 2). Bila mengikuti pelajaran mau mendengarkan dan mentaati aturan guru. 3) Anak mau bergaul dan membantu teman bila mengalami kesulitan . Dalam penelitian ini penulis menggu nakan teknik analisa statistik uji-t dengan rumus sbb :

$$
\mathrm{t}=\frac{\mathrm{Md}}{\sqrt{\frac{\sum \mathrm{X}^{2} \mathrm{~d}}{\mathrm{~N}(\mathrm{~N}-1)}}}
$$

\section{PEMBAHASAN}

Program pembelajaran dengan media tayangan audio visual untuk anak usia dini sangat efektif. Artinya dapat menarik perhatian anak, proses pembelajarannya bermakna yakni dengan melibatkan unsur pengamatan, pendengaran, menirukan contoh-contoh riil suatu tindakan / perbuatan. Hasil penelitian yang diolah melalui analisa uji t sangat signifikan.

Diketahui :

$$
\begin{aligned}
& \mathrm{t}=\frac{0,97}{\sqrt{0,08}} \\
& \mathrm{t}=12,125
\end{aligned}
$$

Jumlah Responden $(\mathrm{N})=34$

$\mathrm{Db}$

T hitung

$$
=\mathrm{N}-1=33
$$

T tabel

$$
=12,125
$$$$
=2,021
$$

Taraf Signifikasi $5 \%=12,125>2,021$

Suatu rumus : Jika signifikasinya uji $t_{\text {hitung }}$ lebih besar dari $t_{\text {tabel }}$ artinya ada pengaruh. Jika signifikasinya uji $t_{\text {hitung }}$ lebih kecil dari $t_{\text {tabel }}$ artinya tidak ada pengaruh. Sesuai hasil analisa data bahwa nilai $t_{\text {hitung }}$ lebih besar dari $t_{\text {tabel }}$ dengan taraf signifikansi 5\% yaitu : $12.125>2.021$, maka hipotesis yang menyatakan ada pengaruh media aodio visual terhadap peningkatan program pembiasaan pada anak kelompok A TK Dharma Wanita Desa Wedi diterima. Selanjutnya hasil rekapan dalam penelitian ini dapat digambarkan sebagai berikut:

Tabel 1. Rekapan Dalam Penelitian

\begin{tabular}{|l|l|l|l|l|l|}
\hline NO & ASPEK & \multicolumn{2}{|c|}{ PRE TES } & \multicolumn{2}{c|}{$\begin{array}{c}\text { NILAI } \\
\text { POST TES }\end{array}$} \\
\hline 1. & SATU & 4 & $1 \mathrm{ak}$ & 4 & $17 \mathrm{ak}$ \\
\hline & & 3 & $11 \mathrm{ak}$ & 3 & $17 \mathrm{ak}$ \\
\hline & & 2 & $21 \mathrm{ak}$ & 2 & - \\
\hline & & 1 & $1 \mathrm{ak}$ & 1 & - \\
\hline 2. & DUA & 4 & - & 4 & $4 \mathrm{ak}$ \\
\hline & & 3 & $10 \mathrm{ak}$ & 3 & $21 \mathrm{ak}$ \\
\hline & & 2 & $21 \mathrm{ak}$ & 2 & $9 \mathrm{ak}$ \\
\hline & & 1 & $3 \mathrm{ak}$ & 1 & - \\
\hline 3. & TIGA & 4 & - & 4 & $6 \mathrm{ak}$ \\
\hline & & 3 & $6 \mathrm{ak}$ & 3 & $23 \mathrm{ak}$ \\
\hline & & 2 & $24 \mathrm{ak}$ & 2 & $5 \mathrm{ak}$ \\
\hline & & 1 & $4 \mathrm{ak}$ & 1 & - \\
\hline
\end{tabular}


Keterangan :

Aspek Satu : Sikap berjabat tangan

Aspek Dua : Sikap disiplin di kelas

Aspek Tiga : Sikap mau berbagi/bergaul

$\mathrm{Ak}=$ Jumlah anak

Selanjutnya dari data tersebut akan penulis bahas secara diskriptif sebagai berikut : Mayoritas anak setelah melihat tayangan pembelajaran dengan media audiovisual dapat melakukan atau menirukan untuk berperilaku sesuai dengan apa yang diharapkan. Misalnya pembiasaan berjabat tangan: Dari 1 anak menjadi 17 anak yang bisa melakukan berjabat tangan dengan sempurna. Mereka bila bertemu dengan ibu guru, teman, atau orang lain, sudah mau bersalaman dengan sikap yang tepat, posisi berdiri dengan wajah menatap, serta mengucap salam dengan kata kata yang jelas dan sempurna.

Memang masih ada 3 anak dari 34 anak yang harus diingatkan untuk berjabat tangan bila bertemu dengan ibu guru atau orang lain. Kelompok anak ini jika berjabat tangan masih memiliki sikap kurang sempurna. Misalnya tidak mau melihat / berpandangan mata, tidak mau mencium tangan, cepat-cepat menarik tangannya, bahkan tidak mau mengucapkan salam.

Misalnya pembiasaan melakukan kedisiplinan di kelas. Sebanyak 25 dari 34 anak. Mereka sudah bisa melakukan kedisiplinan saat mengikuti kegiatan di sekolah. Anak-anak sudah tanggap dan memahami apa yang harus dilakukan dan apa yang harus ditinggalkan pada saat kegiatan di kelas berlangsung. Bila guru mengingatkan anak harus diam, anak harus mendengarkan, dan harus melakukan sesuatu, mayoritas anak bersedia dan bisa melakukan dengan baik / sempurna.

Memang masih ada anak yang kurang disiplin terhadap aturan di kelas. Misalnya saat anak harus duduk dan diam, mereka tetap saja berlari lari, bermain, dan melakukan sesuatu sesuai dengan kesenangannya. Pada saat anak disuruh guru melakukan / mengerjakan sesuatu anak tidak mau, bahkan mau mengerjakan tugas bila tuntutannya harus dipenuhi terlebih dahulu. Misalnya harus diijinkan untuk main-main dahulu, atau harus ditemani dengan teman yang mereka senangi, atau harus dikasih permen, atau permainan lainnya, dsb.

Misalnya pembiasaan saling berbagi.
Sebanyak 29 dari 34 anak sudah bisa tanggap terhadap kondisi lingkungannya. Misalnya bila ada teman yang memerlukan bantuan, pada umumnya anak mau dan bisa membantu temannya. Bila ada teman yang sedang melakukan kegiatan, anak lain sering membantunya, biarpun tidak disuruh. Pada saat anak makan sesuatu, mereka sering berbagi dengan teman lainnya . bila mainan temannya jatuh, maka anak siap dan mau mengambilkannya . Jadi hasil pembahasan dari hasil penelitian dapat disimpulkan bahwa pembelajaran untuk anak usia dini dengan menggunakan tayangan audiovisual membuat mayoritas anak mudah meniru untuk melakukan program pembiasaan, sehingga secara otomatis anak dapat melakukannya dan siap melaksanakannya. Hal ini terbukti pada saat anak memasuki ruangan kelas, sikap anak berjabat tangan dengan guru sudah bagus, mereka melakukan berbaris dengan rapi. Saat memulai belajar anak melakukan berdoa dengan tepat, duduk dengan diam, taat terhadap perintah guru. Bila ingin ke kamar kecil anak juga sudah biasa meminta ijin kepada guru.

Memang masih ada anak yang kurang tanggap terhadap lingkungan atau temannya. Mereka tidak mau berbagi, tidak mau menolong kesulitan teman. Bila mereka mau menolong / berbagi, mereka menentukan terlebih dahulu berbagai persyaratan. Misalnya harus mengasih sesuatu, harus mau disuruh mengambilkan sesuatu. Atau kalau mau berbagi hanya dengan teman teman tertentu saja.

Dengan demikian dalam penelitian ini menunjukkan bahwa pembelajaran menggunakan media audio visual dapat bermanfaat untuk mengatasi permasalahan yang terjadi dalam program pembiasaan anak. Adapun manfaatnya antara lain:

Pembelajaran dengan audio visual akan lebih menarik perhatian anak sehingga dapat menumbuhkan motivasi belajar yang kuat . Karena media ini dapat menjadikan anak senang melihat, mengasyikkan untuk mendengarkan, dan membuat anak mudah meniru apa yang dilihat, serta dapat menarik perhatian atau konsentrasi anak terhadap proses belajar berlangsung.

Bahan pembelajaran yang berupa tayangan audio visual dengan materi contoh contoh perilaku yang baik saat di sekolahan akan lebih jelas maknanya bagi anak sehingga mudah dan 
dapat dipahami oleh anak. Sebab materi tayangan didesain sesuai dengan ciri, watak, serta lingkungan terdekat anak pada setiap harinya.

Metode pembelajaran akan lebih bervariasi sehingga siswa tidak bosan. Pada umumnya metode pembelajaran yang digunakan untuk anak usia dini berkisar dengan bermain, berceritera, serta tugas dan contoh contoh berbentuk tulisan. Dengan metode pembelajaran menggunakan media audio visual merupakan bentuk baru sebagai variasi penggunaan media pembelajaran di PAUD..

Siswa lebih banyak melakukan kegiatan belajar, berfikir dan kegiatan fisik secara aktif. Sebab dengan adanya tayangan audio visual anak tidak hanya mendengarkan uraian dari guru saja, tetapi mereka juga melakukan aktivitas lain seperti mengamati, melakukan (meniru bertingkah laku), mendemons trasikan (mencontoh dan mencocokkan), dan lain sebagainya

Sesuai pendapat Piaget tentang tahap tahap perkembangan anak, bahwa taraf pembalajaran anak usia dini masih memerlukan media / hal hal yang nyata / riil. Jadi yang dominan anak mau dan mudah belajar karena adanya kegiatan pengamatan, pendengaran, dan contoh-contoh riil suatu tindakan / perbuatan. Anak usia dini belum mampu untuk berfikir secara abstrak dan masih bersifat sensori (pengembangan aspek penginderaan, yaitu belajar melalui aspek penglihatan, pendengaran, perabaan, menghidu , dan perasaan ).

\section{KESIMPULAN}

Berdasarkan hasil analisa data maka dapat diambil suatu kesimpulan sebagai berikut:

1. Media audiovisual sangat efektif digunakan sebagai pengembangan sikap perilaku untuk anak usia dini

2. Media audiovisual yang dapat dilihat, didengar, serta ditiru dapat digunakan untuk peningkatan program pembiasaan bagi anak usia dini.

\section{E. DAFTAR PUSTAKA}

Angkoro, R., dan Kosasih, A., 2007. Optimalisasi Media Pembelajaran. Jakarta, Grasindo

Anik Lestariningrum, (2014) Pengaruh Penggunaan Media VCD terhadap Nilai
Nilai Agama dan Moral Anak, Jurnal

Pendidikan Usia Dini, Volume 8 Edisi 2,

November 2014. Halaman195-206

Direktorat Pembinaan Taman Kanak Kanak dan

Sekolah Dasar, 2008, Pengembangan

Model Pembelajaran di Tman Kanak

Kanak, Departemen Pendidikan Nasional,

Direktorat Jenderal Menengah Pendidikan

Dasar dan Menengah, Jakarta, Direktorat

Pembinaan TK dan SD

Fadlillah, M \& Khorida Lilif Mualifatu. (2013). Pendidikan Karakter Anak Usia Dini: Konsep \& Aplikasinya dalam PAUD. Jogjakarta : Ar Ruzz Media

.----------,( 2014). Edutainment Pendidikan Anak

Usia Dini Menciptakan Pembelajaran

Menarik, Kreatif, dan Menyenangkan. Jakarta

: Kencana.

Isabella Hasiana. (2015) , Mengembangkan

Karakter Anak Usia Dini melalui

Permainan Tradisional, Jurnal Buana

Pendidikan, Tahun XI, Nomor 21, Oktober 2015, Halaman 21 - 28

Joko Sutrisno (2010), Pengembangan Media Pembelajaran Berbasis Teknoloi Informasi dan Komunikasi, Wahana, Jurnal Ilmiah Sains \& Ilmu Pendidikan, Vo. 55, Nomor 2, Hal. 33-40

Muniroh, (2014) Pendidikan Karakter dalam Implementasi Kuikulum PAUD, Jurnal Penelitian dan Pengembangan Pendidikan Anak Usia Dini, Tahun 1, nomor 1, Mei 2014, diterbitkan Program PG-PAUD FKIP Universitas Sultan Agung Tirtayasa, hal. 53 - 58

Noorlaili, Iva. 2010. Panduan Lengkap Mengajar PAUD. Yogyakarta: Pinus Bookpublisher

Permendiknas Nomer 58 tahun 2009, Tentang

Standar Pendidikan Anak Usia Dini,

Depdiknas , Jakarta, 2009

Rita Eka Izzaty S., 2005, Menggali Permasalahan Perkembangan Anak, Depdikbud, Dirjen Dikti, Jakarta

Sri Anitah, dkk. (2007). Strategi Pembelajaran di TK. Jakarta: Universitas Terbuka.

Suci Rahayu, (2014) Kebiasaan Makan Anak Kecamatan Pulogadung, Jurnal Pendidikan Usia Dini, Volume 8 Edisi 1, April 2014. Halaman165-174

Sudjana. N. 1989. Media Pengajaran. Bandung, CV Sinar baru. 
Sudono, Anggani. (2010). Sumber Belajar dan Alat Permainan untuk Pendidikan Anak Usia Dini . Jakarta: PT Grasindo.

Sujiono, Yuliani Nurani, Menu Pembelajaran Anak Usia Dini, Jakarta, Citra Guruan, 2005

------, Konsep Dasar Pendidikan Anak Usia Dini, Jakarta, PT Indeks, 2009

Susanto, Ahmad. (2011). Perkembangan Anak Usia Dini: Pengantar Dalam Berbagai Aspeknya. Jakarta: Kencana Prenada Media Group.

Suyono, (2010) Pengaruh Penggunaan Strategi Pembelajaran terhadap Hasil Belajar PKN siswa SMP Negeri 1 dan 2 Gedangan Sidoarjo yang memiliki tingkat motivasi belajar yang berbeda, Jurnal Buana Pendidikan, Tahun VI, Nomor 11, Oktober 2010, Hal $30-41$

Yuliani Nurani Sujiono, dkk., (2007), Metode Pengembangan Kognitif, Universitas Terbuka, Dirjen Dikti, Jakarta

Undang Undang Nomor 20 Tahun 2003, tentang Sistem Pendidikan Nasional, Jakarta 